\title{
A prospective project of microbiological surveillance at a teaching Hospital in Italy; evolving epidemiological features, and in vitro antimicrobial sensitivity trends
}

Roberto Manfredi

From $16^{\text {th }}$ International Symposium on HIV and Emerging Infectious Diseases

Marseille, France. 24-26 March 2010

\section{Background}

An active bacteriological surveillance project is part of the mandatory knowledge on the local microbial isolation and their antimicrobial resistance pattern.

\section{Methods}

The trend of microbial isolations from patients admitted in the last year 2008 (January 1, 2008-December 31, 2008) at our Hospital is reported on quarterly basis, together with updated antimicrobial sensitivity testing.

\section{Results}

As a whole, Gram-negative agents showed an increasing trend of isolation, regardless of the examined clinical specimens, while the epidemiology of Staphylococci remained somewhat unchanged, and their methicillin resistance rate remained under control (around 39\% of overall isolates from blood cultures). When considering Enterococci, the active surveillance of VRE strains successfully acted against the potential nosocomial spread of these organisms: the only 7 cases of "Van A" Enterococcus faecalis strains were not related with each other, and glycopeptide resistance remained limited to less than 3\% of overall Enterococci. An increasing number of ESBL-producing Enterobacteriaceae was noticed (with a $29-36 \%$ quarterly rate for Escherichia coli, and up to $41 \%$ for other organisms, as a whole). The overall resistance rate against fluoroquinolones is on steady increase: the last quarterly report shows a $47.3 \%$ rate for E. coli,

Correspondence: Roberto.manfredi@unibo.it

Infectious Diseases, University of Bologna, S. Orsola Hospital, Bologna, Italy
$30.8 \%$ for Enterobacteriaceae, and $42.6 \%$ for Pseudomonas aeruginosa.

\section{Discussion}

An active, prospective microbiological monitoring may significantly add to the knowledge of local epidemiological figures and antimicrobial sensitivity trends, and plays a role of paramount importance when selecting and planning chemoprophylaxis and therapeutic strategies, on a local and regional basis.

Published: 11 May 2010

doi:10.1186/1742-4690-7-S1-P171

Cite this article as: Manfredi: A prospective project of microbiological surveillance at a teaching Hospital in Italy; evolving epidemiological features, and in vitro antimicrobial sensitivity trends. Retrovirology 2010 7(Suppl 1):P171.
Submit your next manuscript to BioMed Central and take full advantage of:

- Convenient online submission

- Thorough peer review

- No space constraints or color figure charges

- Immediate publication on acceptance

- Inclusion in PubMed, CAS, Scopus and Google Scholar

- Research which is freely available for redistribution

Submit your manuscript at www.biomedcentral.com/submit
C Biomed Central 